\title{
Brief Discussion on the Shortcomings and Perfection of Negotiorum Gestio in China
}

\author{
Nannan Chen \\ The Oriental Institute of Shandong University of Finance and Economics, Shandong, China
}

Keywords: negotiorum gestio; current situation of legislation; system improvement

\begin{abstract}
In china, the present legal provision of negotiorum gestio is in article 93 of "General Principles of the Civil Law" and article 132 of "the Opinions of General Principles of the Civil Law". The two articles only mentioned the definition and right. Therefore, there are still many loopholes in the relevant laws which need to be improved and simple content which cannot adapt to the real life.
\end{abstract}

\section{Introduction}

\subsection{Negotiorum gestio status in civil law.}

Negotiorum gestio means that although the manager has no right or obligation to interfere in the lives of others, he is involved in his affairs for the benefit of others. From the autonomy principle in civil law, it is illegal for people to interfere with other people's behavior without the trust and commitment of others. From the point of altruism, "for others", it is in accordance with the spirit of the law. The relationship between this kind of manager and his people's creditor's rights and debts is regulated by the negotiorum gestio.

\subsection{Current situation of negotiorum gestio legislation.}

As one of the main legal facts about the debt occurrence, negotiorum gestio originated from the Roman law, which obtain limited development after experiencing the historical precipitation for thousands of years. In the Anglo-American legal system, there is no concept or related system for negotiorum gestio. In the traditional civil law countries, it has not grown up because of its long history.in china, we have two articles about negotiorum gestio: article 93 of "General Principles of the Civil Law" and article 132 of "the Opinions of General Principles of the Civil Law". The two articles just told us the definition and the rights that can be enjoyed by the manager. There are still many loopholes in the relevant laws, which need to be improved. Its content is too simple to adapt to the real life. It is a great significance to construct a good relationship between people, which can promote the construction of social spiritual civilization.

\section{Shortcomings of negotiorum gestio in China}

Although negotiorum gestio exists in "General Principles of the Civil Law" and "the Opinions of General Principles of the Civil Law", But with the increasing of people's demands, the problem become obvious. The author thinks that the current domestic legislation still has the following problems.

The article 93 of in "General Principles of the Civil Law" in China does not stipulate the applicable conditions of negotiorum gestio. It is a difficult problem to accurately apply the system in real life. In the early days, it is a typical case to deal with Good Samaritan in article 109 of "General Principles of the Civil Law" and article 142 "the Opinions of General Principles of the Civil Law".

The constitutive elements of the negotiorum gestio are also used to distinguish the negotiorum gestio behavior and other behaviors. The theory of constitutive elements plays a vital role in the improvement and improvement of our country's future. 
The existing legal provisions on the negotiorum gestio in China are simply provided for the right of the administrator, including the right to claim and claim for damages. This is very detrimental to the protection of managers' interests, which need to be further improved.

The existing legal provisions on the negotiorum gestio in China has no word on the administrator's liability and disclaimer, which need to be further improved.

The existing legal provisions on the negotiorum gestio in China does not deal with the relationship with other institutions, which include the relationship between negotiorum gestio and unauthorized agency, and the relationship between negotiorum gestio and delegation. This is also shortage to protect the interests of managers.

The existing legal provisions on the negotiorum gestio in China only involves the real negotiorum gestio. There has no explicit stipulation on the quasi negotiorum gestio.we need to add quasi negotiorum gestio.

The writer believes the division of negotiorum gestio has the legal significance that different legal facts result in different legal results. The essential difference between the two is whether there is resistance but illegality. Therefore, it cannot be regarded as a lawful act without the quasi negotiorum gestio of this property. However, in order to protect the own interests, it may be allowed to liquidate all interests based on the requirements of the manager without any cause [2].

Good Samaritan as a special kind of negotiorum gestio act, the law does not make clear regulation on the violator damage compensation. We should clear the damage compensation system, which will improve the confidence and enthusiasm of the brave.

\section{Perfection of Negotiorum gestio}

\subsection{Increase quasi negotiorum gestio.}

For example: A published novel on the Internet, B took the novel after reading the novel to make it cartoon and gain huge profits. Question: What kind of request does A make to B?

The "management of other people's affairs" that not for others

It is believed that the act of managing others' affairs for the benefit of others is negotiorum gestio. The real negotiorum gestio requires the manager to have the management meaning, and the purpose of serving and managing others. On the contrary, the behavior of service and management to others for their own benefit constitutes quasi negotiorum gestio [3].

What if the actor, by virtue of the opportunity to manage other people's affairs, seeks to profit from the interests of others in the interests of his own interests? If there is no cause for management, then the manager must pay the full benefit to himself. But because the meaning of "not in person", "is not based on the meaning of altruistic behavior" such as reason, usually turns to the unjust enrichment or tort for processing. In this case, the "intervener" bears the "return of interest (loss)" to the victim (Section 703 of the Japanese civil code) and "damage compensation" (Section 709 of the Japanese civil code) to the victim. But no matter what, the damage in person is limited [1].

\subsection{Increase the negotionrum gestion.}

Negotionrum gestion is the negotiorum gestio that not lawful to take responsibility for other people's affairs, which is harmful to the own interests or to deviate from the own express or inferential meaning, without proper legal basis. In terms of definition, although it violates the spirit of the negotionrum gestion, and lacks the intention of managing the affairs for the benefit of others, it still belongs to the category of real negotionrum gestion. In future's civil law. There should have a careful division between the proper method and the inappropriate method for the real negotionrum gestion. We can divide the negotionrum gestion into three conditions: firstly, unfavorable to the person, which deviates from the own meaning and harms its interests. For example: replace the natural debt that the other person has refused to pay. Secondly, favorable to the person, which deviates from the own meaning but beneficial to its unimpeded management. For example, A sold B's old paintings in order to pay the doctor's bills. Thirdly, suite for the person's mind, which deviates from the own meaning but harmful to its management. For example, Pay off other people's 
gambling debts.

Negotionrum gestion concentrated with not to be entrusted, but to administer affairs for others and no valid legal basis for any harm to the interests of the person or to the intention of either express or infer. The first requirement, which has been dealt with in the context of the preceding article, the writer will introduce the second requirement.

In contravention of the own meaning, it is a violation of the own express or inferred intention. For example, A saw smoke in the home of B, thinking that there was a fire, so he bought the fire extinguisher to break into the house and rushed to the kitchen, only to find that B was cleaning the burnt bread. The legal basis refers to the management of the public welfare or legal obligations.

\subsection{Content refinement of real negotiorum gestio.}

The negotiorum gestio should increase and refine the manager's obligations and further improve the rights of the manager. Negotionrum gestion should increase and refine the administrator's obligations and my rights and obligations. For example, the administrator's obligation can increase and refine the administrator's tort liability, the aggravation of the administrator's responsibility, and the reduction of the administrator's responsibility. The person's rights and obligations can be divided into two situations: claim to enjoy the benefit of the negotiorum gestio or not.

\section{Legal Provisions Design of Negotiorum gestio in China}

\subsection{Improve the rights and obligations of the administrator.}

There is no statutory or contractual obligation to voluntarily manage the affairs or property of another person, so that others may benefit or avoid the loss of the benefit. This is the negotiorum gestio.

The manager shall protect the interests of other persons in a manner consistent with his or her own express or inferred.

The administrator has a way to inform the person of the responsibility that has been initiated and is known to the person.

When the act of negotiorum gestio begins, the administrator shall perform the obligation to report to the person on the management and calculation under the circumstances which may be the case.

The right to reimburse the necessary expenses. The "necessary expenses" here are the necessary or beneficial costs and the interest accrued from the time spent. All the necessary expenses manager may request repayment. The criteria for measuring whether the costs are necessary shall be determined according to the actual situation.

As long as it is necessary or beneficial to the person, the administrator may, after undertaking the transaction management process, claim the debt repayment.

The manager shall be entitled to request repayment from the manager in the event of a causal relationship between the damage and the management. If the manager is at fault for the loss of injury, it is reasonable to reduce his liability according to the actual situation.

In accordance with the principle of fairness, the right of remuneration of the manager can be appropriately affirmed under the following conditions. That is, the person has benefited from the management of the management.

\subsection{Administrator's responsibility and disclaimer.}

The conduct of other people's affairs is detrimental to the interests of the person or the behavior that deviates from its express or inferential meaning, so as to make it illegal for the negotiorum gestio to lose its resistance and violate the law. Therefore, if the administrator infringes on the person's right and is intentional or negligent, the person shall be liable for compensation in accordance with the tort.

The manager deviates from the person or can infer the meaning of the speculation. As long as the management results infringe on the interests of the person, even if the manager is not negligent, it 
should be liable for compensation.

When the personal and property safety of the person is in danger of emergency, the management of the management to eliminate its danger is the management behavior, even if it causes harm to the person, in principle, it is not liable for compensation. Unless the manager carries out the act out of good will or gross negligence.

\subsection{Clear the person's claim.}

Return the right of claim. After the negotiorum gestio, the manager shall be liable for the benefits arising from the activity. In case of no delivery or delay in delivery, the person may request the return.

Claim of compensation for damage. The person hurt in the process of negotiorum gestio and suffer losses, is because the manager has not done good manager or the duty of subjective fault as a result, the person will have the right to request compensation.

The person's choice. In the negotionrum gestion, the content of the person's rights and obligations will vary depending on the circumstances.

Claim to enjoy the benefit of the negotiorum gestio. In such case, the person shall bear the necessary expenses, pay off the necessary debts and indemnify the administrator at the same time. Of course, the foregoing obligation shall be subject to the maximum benefit that the person can obtain in the absence of management.

Not claim to enjoy the benefit of the negotiorum gestio as well as no obligation. At this time, the legal relationship between the parties can be dealt with according to unjust enrichment and the rules of tort.

\subsection{Clear the applicable law of negotionrum gestion.}

In the case of negotionrum gestion, it should be handled according to the law of tort or unjust enrichment.

For illegal management, it should be handled according to the law of tort or unjust enrichment. But if claim tort damages or lost the unjust enrichment is advocate negotiorum gestio party benefit, can be illegal negotiorum gestio of provisions shall be applicable to the management and so on, the person can return to managers claim all interests.

But in this case, there must be a strict application of the premises - knowing that it is the business of others to manage it. Therefore, the management of the manager caused by "negligence" should still be handled according to the law of tort or unjust enrichment.

\subsection{Clear the damage compensation system of Good Samaritan.}

If the actor is injured and suffers from the loss, he can either claim damages to the infringer or ask the beneficiary for reasonable compensation. The infringer and the beneficiary are jointly and severally liable, which means the actor may choose the beneficiary to pay the compensation in advance, and the beneficiary must not refuse. After accepting the responsibility, he has the right to claim compensation from the infringer.

In order to eliminate and reduce the damage caused by natural factors, the actor shall be entitled to claim full compensation from the beneficiary for his injury and loss.

\section{References}

[1] [Japan] Yasuo Ishizaki, Watanabe Yodo. New. Handout of Civil Law 5: Negotiorum Gestio. Unjust Enrichment. Tort Law [M]. Tokyo: Nintendo Co., Ltd., 2011: 46

[2] Ma Junju, etc. The Theory of Civil Law (Volume 2) [M]. Beijing: Law Press China, 1998: 368-370.

[3] [Japan] Tamaki Uchida. Creditor's rights and the theory of Civil law II [M]. Tokyo: University of Tokyo Press, 2011: 565. 